\title{
Late Lyme neuroborreliosis with chronic encephalomyelitis
}

Isabelle Beuchat, MD, Vincent Dunet, MD, Pascal Meylan, MD, and Renaud Du Pasquier, MD

Neurology ${ }^{\circledR}$ 2018;91:627-628. doi:10.1212/WNL.0000000000006252
Correspondence

Dr. Beuchat

Isabelle.beuchat@chuv.ch

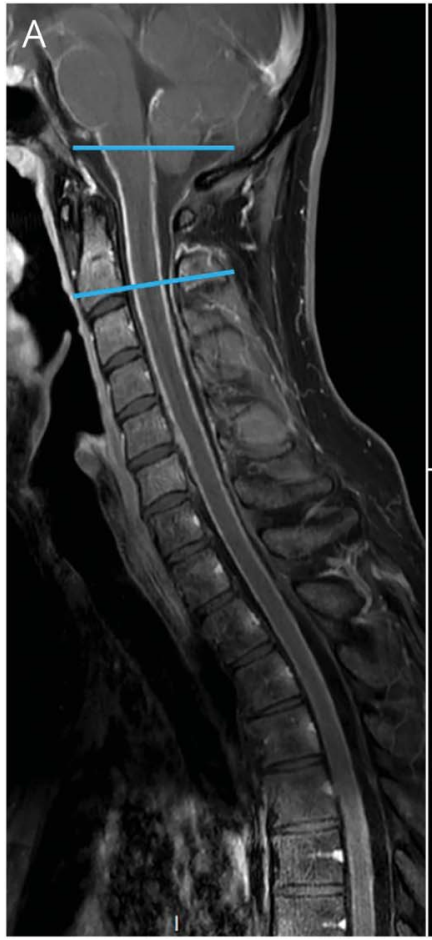

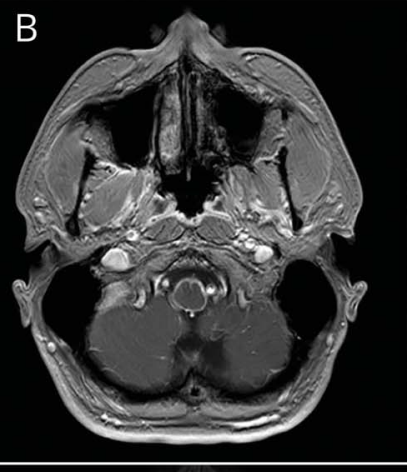

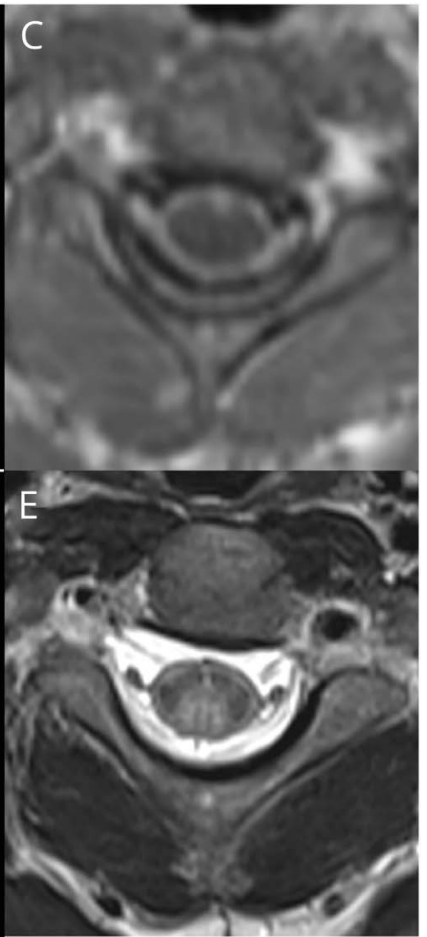

(A-C) Postcontrast T1-weighted imaging reveals leptomeningeal enhancement along the pons, the myelencephalon, and the spinal cord. Fluid-attenuated inversion recovery (D) and T2-weighted images (E) reveal peripheral hyperintensity of the myelencephalon (D), of the cervical cord, and in the fasciculus gracilis and fasciculus cuneatus (E). Lines across (A) represent the location of the axial images (top line: B-D, bottom line: C-E).

A 34-year-old man developed, over 7 months, progressive gait disorder and sphincter dysfunction. Examination demonstrated spastic and ataxic paraparesis. MRI revealed extensive meningomyelitis (figure). Anti-Borrelia burgdorferi $(\mathrm{Bb})$ immunoglobulin $\mathrm{G}$ (IgG) was positive (by Vidas ELFA, BioMérieux [Marcy-l'Étoile, France], $\mathrm{n}<0.2$ ) in the serum (index 6.85) and in the CSF (index 2.68), as was immunoglobulin $M$ in the serum (index 0.54). Lumbar puncture demonstrated pleocytosis (195 leukocytes/ $\mu \mathrm{L}$ ) and intrathecal synthesis of anti-Bb IgG antibody production (intrathecal synthesis ratio $=4$ after correcting for CSF $/$ serum albumin ratio, $\mathrm{n}<2$ ). After 4 weeks IV ceftriaxone $2 \mathrm{~g}$ daily, the status showed significant improvement. Late Lyme neuroborreliosis, defined as continuous disease lasting more than 6 months, represents less than 2\% of all Lyme neuroborreliosis. Definite diagnosis can be made in the presence of suggestive neurologic symptoms, CSF pleocytosis, and intrathecal $\mathrm{Bb}$ antibody production. ${ }^{1,2}$

\section{Author contributions}

Dr. Beuchat: clinical assessment, case report concept, drafting and revising the manuscript. Dr. Dunet: provided the figure images, analyzed the radiologic images, performed critical

From the Service of Neurology, Department of Clinical Neuroscience (I.B., R.D.P.), Department of Diagnostic and Interventional Radiology (V.D.), and Institute of Microbiology (P.M.), Centre Hospitalier Universitaire Vaudois (CHUV) and University of Lausanne, Switzerland.

Go to Neurology.org/N for full disclosures. Funding information and disclosures deemed relevant by the authors, if any, are provided at the end of the article. 
revision of the manuscript content. Prof. Meylan: analyzed the biological data, performed critical revision of the manuscript for important intellectual content. Prof. Du Pasquier: clinical assessment, critical revision of the manuscript for important intellectual content.

\section{Study funding}

No targeted funding reported.

\section{Disclosure}

The authors report no disclosures relevant to the manuscript. Go to Neurology.org/N for full disclosures.

\section{References}

1. Koedel U, Fingerle V, Pfister HW. Lyme neuroborreliosis: epidemiology, diagnosis and management. Nat Rev Neurol 2015;11:446-456.

2. Mygland A, Ljostad U, Fingerle V, et al. EFNS guidelines on the diagnosis and management of European Lyme neuroborreliosis. Eur J Neurol 2010;17:8-16, e1-e4.

\section{A New Generation of Fall Conference}

Register today for the 2018 Fall Conference taking place October 26 through 28 in Las Vegas and experience an enhanced and expanded program complete with some of the most popular education courses and breakthrough scientific research from the record-setting 2018 Annual Meeting.

Visit AAN.com/view/fall today.

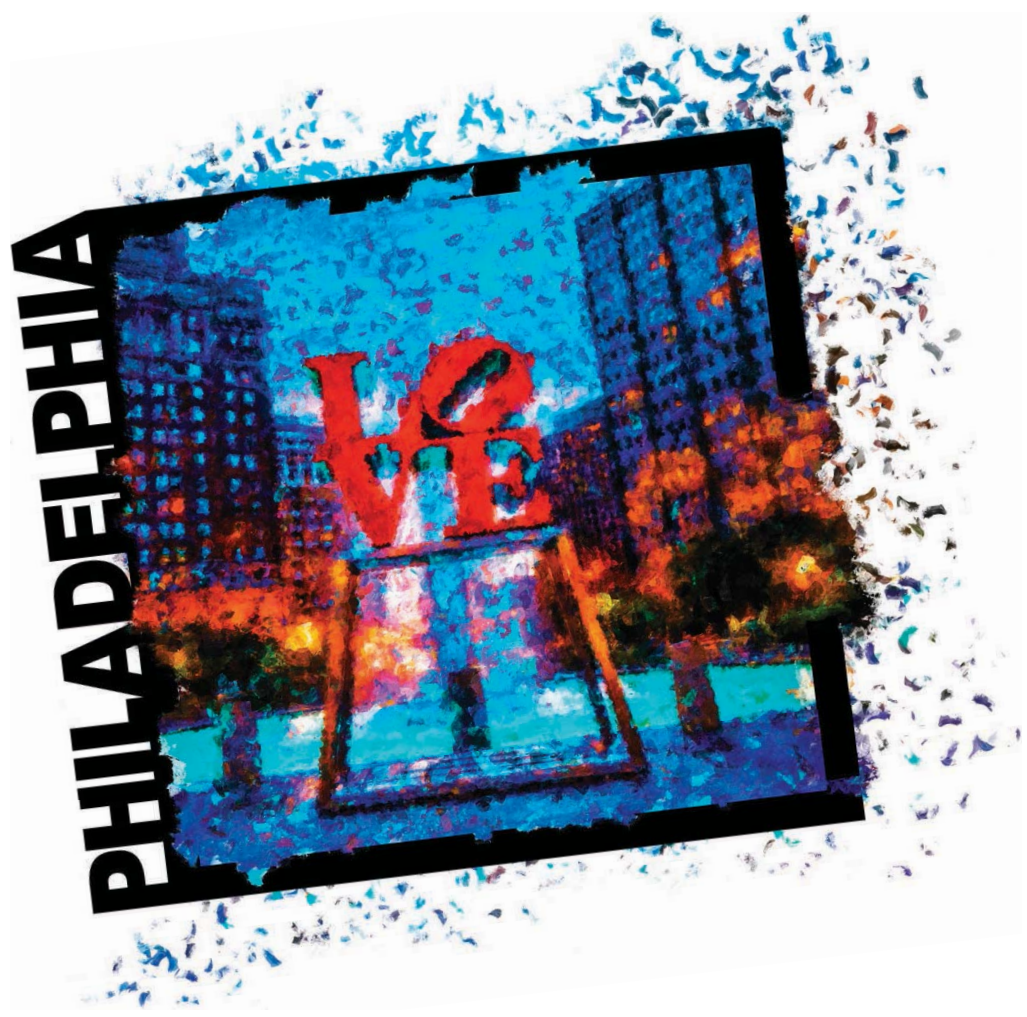

ADVANCING NEUROLOGY. ADVANCING YOU.

\section{IMPORTANT DATES AND DEADLINES}

Don't miss these important dates for the 2019 AAN Annual Meeting, set for May 4-10, 2019, in Philadelphia.

Learn more at AAN.com/view/AM19

- Abstract Submission Deadline: October 22, 2018

- Awards Application Deadline: October 24, 2018 


\section{Neurology}

\section{Late Lyme neuroborreliosis with chronic encephalomyelitis}

Isabelle Beuchat, Vincent Dunet, Pascal Meylan, et al.

Neurology 2018;91;627-628

DOI 10.1212/WNL.0000000000006252

This information is current as of September 24, 2018

\section{Updated Information \&} Services

\section{References}

Subspecialty Collections

Permissions \& Licensing

Reprints including high resolution figures, can be found at: http://n.neurology.org/content/91/13/627.full

This article cites 2 articles, 0 of which you can access for free at: http://n.neurology.org/content/91/13/627.full\#ref-list-1

This article, along with others on similar topics, appears in the following collection(s):

Bacterial infections

http://n.neurology.org/cgi/collection/bacterial_infections Encephalitis

http://n.neurology.org/cgi/collection/encephalitis

\section{MRI}

http://n.neurology.org/cgi/collection/mri

Spinal cord infection

http://n.neurology.org/cgi/collection/spinal_cord_infection

Information about reproducing this article in parts (figures,tables) or in its entirety can be found online at:

http://www.neurology.org/about/about_the_journal\#permissions

Information about ordering reprints can be found online:

http://n.neurology.org/subscribers/advertise

Neurology ${ }^{\circledR}$ is the official journal of the American Academy of Neurology. Published continuously since 1951, it is now a weekly with 48 issues per year. Copyright @ 2018 American Academy of Neurology. All rights reserved. Print ISSN: 0028-3878. Online ISSN: 1526-632X.

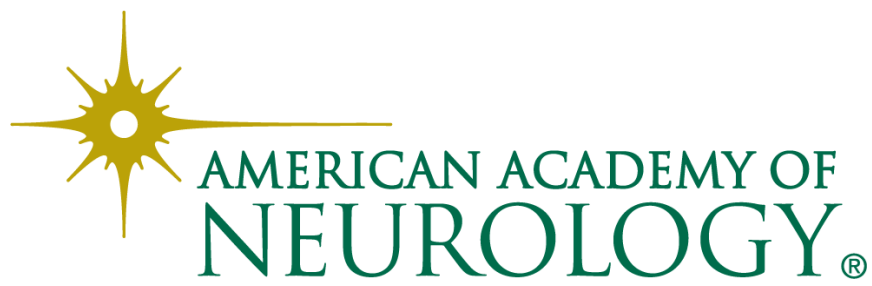

